Authors' contribution/

Wkład autorów:

A. Zaplanowanie badań/

Study design

B. Zebranie danych/

Data collection

C. Analiza statystyczna/

Statistical analysis

D. Interpretacja danych/

Data interpretation

E. Przygotowanie tekstu/

Manuscript preparation

F. Opracowanie

piśmiennictwa/

Literature search

G. Pozyskanie funduszy/

Funds collection
ISSN 2083-3725

Volume 10, No. 2, 2017

\section{PERSPECTIVES OF GEOTOURISM DEVELOPMENT IN THE GORCE I QUARRY}

\section{PERSPEKTYWY ROZWOJU GEOTURYSTYKI W KAMIENIOŁOMIE GORCE I}

\author{
tukasz Zbucki $^{1(\mathrm{~A}, \mathrm{~B}, \mathrm{D}, \mathrm{E}, \mathrm{F}, \mathrm{G})}$, Maciej Jędrusik ${ }^{2}(\mathrm{~A}, \mathrm{~B}, \mathrm{D}, \mathrm{E})$
}

${ }^{1}$ Pope John Paul II State School of Higher Education in Biała Podlaska,

Faculty of Economic and Technical Sciences,

Państwowa Szkoła Wyższa im. Papieża Jana Pawła II w Białej Podlaskiej,

Wydział Nauk Ekonomicznych i Technicznych,

${ }^{2}$ University of Warsaw, Faculty of Geography and Regional Studies, Department of World Regional Geography

Uniwersytet Warszawski, Wydział Geografii i Studiów Regionalnych, Zakład Geografii Regionalnej Świata

Zbucki Ł., Jędrusik M. (2017), Perspectives of geotourism development in the Gorce I quarry/ Perspektywy rozwoju geoturystyki w kamieniołomie Gorce I. Economic and Regional Studies, Vol. 10, No. 2, pp. 96-106. https://doi.org/10.2478/ers-2017-0018

\section{ORIGINAL ARTICLE}

JEL code: Q26

Submitted:

July 2016

Accepted:

October 2016

Tables: 0

Figures: 7

References: 16

ORYGINALNY ARTYKUE NAUKOWY

Klasyfikacja JEL: Q26

Zgłoszony:

lipiec 2016

Zaakceptowany:

październik 2016

Tabele: 0

Rysunki: 7

Literatura: 16

\section{Summary}

Subject and purpose of work: The purpose of the study is to present the perspectives of geotourism development in the porphyry quarry Gorce I, which is situated in the Wałbrzyskie mountains. Currently the exploitation of this quarry is suspended.

Materials and methods: This work was written after studying the literature on this subject and conducting field research, during which terrestrial laser scanning (TLS) was used, among others. The material gathered during field research was used, among other things, to create a 3D model of the Gorce I quarry.

Results: The research and analyses conducted in the porphyry quarry Gorce I allowed for designating a geotourist trail where information boards were placed.

Conclusions: The research conducted in the Gorce I quarry confirms the possibility of utilizing this excavation pit for geotourism purposes.

Keywords: geotourism, quarry, tourist infrastructure

\section{Streszczenie}

Przedmiot i cel pracy: Celem pracy jest przedstawienie perspektyw rozwoju geoturystyki w kamieniołomie porfirów Gorce I, który położony jest w Górach Wałbrzyskich. Obecnie eksploatacja w nim jest wstrzymana.

Materiały i metody: Praca została napisana dzięki studiom literatury przedmiotu oraz przeprowadzonym badaniom terenowym, podczas których wykorzystano między innymi naziemny skaning laserowy (TLS). Zgromadzony materiał podczas badań terenowych, posłużył, między innymi, do wykonania modelu 3D kamieniołomu Gorce I.

Wyniki: Przeprowadzone badania i wykonane analizy w kamieniołomie porfirów Gorce I pozwoliły na wyznaczenie ścieżki geoturystycznej, na której zlokalizowano tablice informacyjne.

Wnioski: Przeprowadzone badania w kamieniołomie Gorce I potwierdzają możliwość wykorzystania tego wyrobiska dla potrzeb geoturystyki.

Słowa kluczowe: geoturystyka, kamieniołom, zagospodarowanie turystyczne 


\section{Introduction}

There are over 5,000 open-pit mines in Poland, of which 900 are hard rock pits (quarries) and openpit mining occupies an area of approximately 26.3 thousand ha, including around 11.9 thousand ha of rock mines (Kasztelewicz, Ptak 2011). The Midas service centre run by the Polish Geological InstituteNational Research Institute does not list numerous small mine pits, where "unregulated" exploitation for local needs is conducted or where mining has been abandoned. It is estimated that the number of deposits and sites where rock materials are extracted is in excess of 10000 (Nita 2013). According to the Polish legislation, after the completion of mining operations and after extraction of mineral deposits an entrepreneur shall be obliged to perform land reclamation and development (Geological and Mining Law 1994).

An increase in the popularity of geotourism has been observed in the recent years. According to T. Słomka and A. Kicińska-Świderska (2004) it is part of cognitive tourism and/or tourism focused on experience, based on exploring geological sites and processes as well as on aesthetic experience from contacts with them. Quarries, where it is possible to observe the effects of geological processes, are great places to pursue geotourism understood this way. Collector specimens of minerals and fossils can often be found here. Quarries may also make the existing landscape more attractive (Chwastek et al. 1992).

\section{Purposes of the study}

The purpose of the study is to present the prospects for the development of geotourism in the Gorce I quarry. Exploitation of this quarry pit is currently (2016) suspended. This work presents the qualities of the quarry which determine its attractiveness for geotourism. During the research attention was focused on the redevelopment of the quarry itself, without considerations for the surrounding area and a range of problems occurring there in connection with accommodation facilities, catering or transportation.

Making the Gorce I quarry available for geotourism requires designation of logical and attractive geotourist trails within its territory. Their main aim is to popularize geological knowledge combined with active recreation. Designation of geotourist trails requires taking into consideration of a number of natural and anthropogenic factors occurring in the quarry pit (Janočková et al. 2012). The safety of tourists is extremely important while designating the trail.

\section{Field research}

Field research in the quarry was conducted by means of a terrestrial 3D laser scanner. Terrestrial laser scanning (TLS) finds application in documenting quarries (Kovanice, Blišt’an 2014 González-Aguilera et al. 2012).

\section{Wstęp}

W Polsce jest ponad 5 tysięcy powierzchniowych wyrobisk górniczych, w tym ponad 900 to wyrobiska skał zwięzłych (kamieniołomy), a górnictwo odkrywkowe zajmuje powierzchnię około 26,3 tys. ha, w tym skalne około 11,9 tys. ha (Kasztelewicz, Ptak 2011). W serwisie Midas prowadzonym przez Państwowy Instytut Geologiczny-Państwowy Instytut Badawczy nie są ujęte liczne małe wyrobiska, w których prowadzona jest „dzika” eksploatacja dla potrzeb lokalnych lub wydobycie zaniechano. Szacuje się, że w Polsce liczba złóż i miejsc wydobycia surowców skalnych wynosi ponad 10000 (Nita 2013). Zgodnie z obowiązującymi w Polsce przepisami prawa, przedsiębiorca po zakończeniu działalności górniczej zobowiązany jest do rekultywacji gruntów i zagospodarowania terenu po wydobyciu kopaliny ze złoża (Prawo geologiczne i górnicze 1994).

W ostatnich latach zauważalny jest wzrost popularności geoturystyki, która według T. Słomki i A. Kicińskiej-Świderskiej (2004) jest działem turystyki poznawczej i/lub nastawionej na przeżycia, bazującej na poznawaniu obiektów i procesów geologicznych oraz doznawaniu w kontakcie z nimi wrażeń estetycznych. Doskonałym miejscem do uprawiania tak rozumianej geoturystyki są kamieniołomy, w których istnieją możliwości obserwacji efektów procesów geologicznych. Często można zebrać tutaj kolekcjonerskie okazy minerałów, czy skamieniałości. Kamieniołomy mogą również uatrakcyjniać istniejący krajobraz (Chwastek i in. 1992).

\section{Cele pracy}

Celem pracy jest przedstawienie perspektyw rozwoju geoturystyki w kamieniołomie Gorce I. W tym wyrobisku obecnie (2016 r.) eksploatacja jest wstrzymana. W pracy przedstawiono walory kamieniołomu, które decydują o jego atrakcyjności geoturystycznej. Podczas badań skupiono się na zagospodarowaniu samego kamieniołomu, nie uwzględniając jego otoczenia i szeregu problemów tam występujących związanych z bazą noclegową, żywieniową, czy transportem itp.

Udostępnienie kamieniołomu Gorce I dla potrzeb geoturystyki wymaga wyznaczenia na jego terenie logicznych i atrakcyjnych ścieżek geoturystycznych. Głównym ich celem jest popularyzacja wiedzy geologicznej połączonej z aktywnym wypoczynkiem. Wyznaczenie ścieżek geoturystycznych wymaga uwzględnienia szeregu czynników naturalnych i antropogenicznych występujących $\mathrm{w}$ wyrobisku (Janočková i in. 2012). Niezwykle istotne jest podczas wytyczania szlaku bezpieczeństwo turystów.

\section{Badania terenowe}

Badania terenowe $\mathrm{w}$ kamieniołomie wykonano naziemnym skanerem laserowym 3D. Naziemny skaning laserowy (TLS) ma zastosowanie w dokumentacji kamieniołomów (Kovanič, Blišt’an 2014, González-Aguilera i in. 2012). 
A beam of coherent light is sent by the scanner during the measurement. The light is reflected by an obstacle and then returns to the device. The information about the duration of the beam travel (the travel from the device to a point and back) and the vertical and horizontal angle at which the light beam arrives at an object is stored on the internal drive. The saved data allow for calculating the spatial coordinates of the point (Pilecki 2012). Recorded points enable formation of the so-called points cloud, which is a type of spatial documentation, where each of the measuring points has a specific location in the XYZ system. The recorded points constitute a baseline data for further analysis.

Research for the Gorce I quarry was conducted in October 2014 using a Riegl VZ-4000 laser scanner. Records were made for 16 positions (Figure 1). Over 121.3 million points were saved during the scanning. They allowed for, among others, making detailed measurements of the quarry pit and the creation of a spatial model in the RiScan family of programs. (Figure 2).

A series of measurements, for example of the surface of the quarry pit, the height of its walls and distances were made in the course of indoor studies on the basis of the collected material. The analysis of visibility in the quarry pit was conducted by means of the created 3D models and ArcGIS family of software. For the purpose of the analysis the average height
Podczas pomiaru ze skanera wysyłana jest wiązka światła koherentnego, które po odbiciu się od przeszkody powraca do urzązenia. Na dysku wewnętrznym skanera zapisywane są informacje o czasie przebiegu wiązki (od urządzenia do punktu i z powrotem) oraz kącie pionowym i poziomym, pod którym wiązka światła natrafia na obiekt. Zapisane dane pozwalają na obliczenie współrzędnych przestrzennych punku (Pilecki 2012). Zapisane punkty pozwalają na utworzenie tak zwanej chmury punktów, która jest rodzajem dokumentacji przestrzennej, gdzie każdy z punktów pomiarowych ma określone położenie w układzie X, Y, Z. Zapisane punkty są danymi wyjściowymi do dalszych analiz.

Badania dla kamieniołomu Gorce I wykonano w październiku $2014 \mathrm{r}$. skanerem laserowym Riegl VZ-4000. Zapis przeprowadzono z 16 stanowisk (rysunek 1). Podczas skaningu zapisano ponad 121,3 mln punktów, które w rodzinie programów RiScan pozwoliły między innymi na szczegółowe pomiary wyrobiska oraz na stworzenie modelu przestrzennego (rysunek 2).

Podczas opracowań kameralnych na podstawie zgromadzonego materiału wykonano szereg pomiarów np. powierzchni wyrobiska, wysokości ścian, odległości. Dzięki stworzonym modelom 3D i oprogramowaniu z rodziny ArcGIS wykonano analizy widoczności w wyrobisku. Do analizy przyjęto średni wzrost dorosłego Polka, który wynosi 172 cm (http://

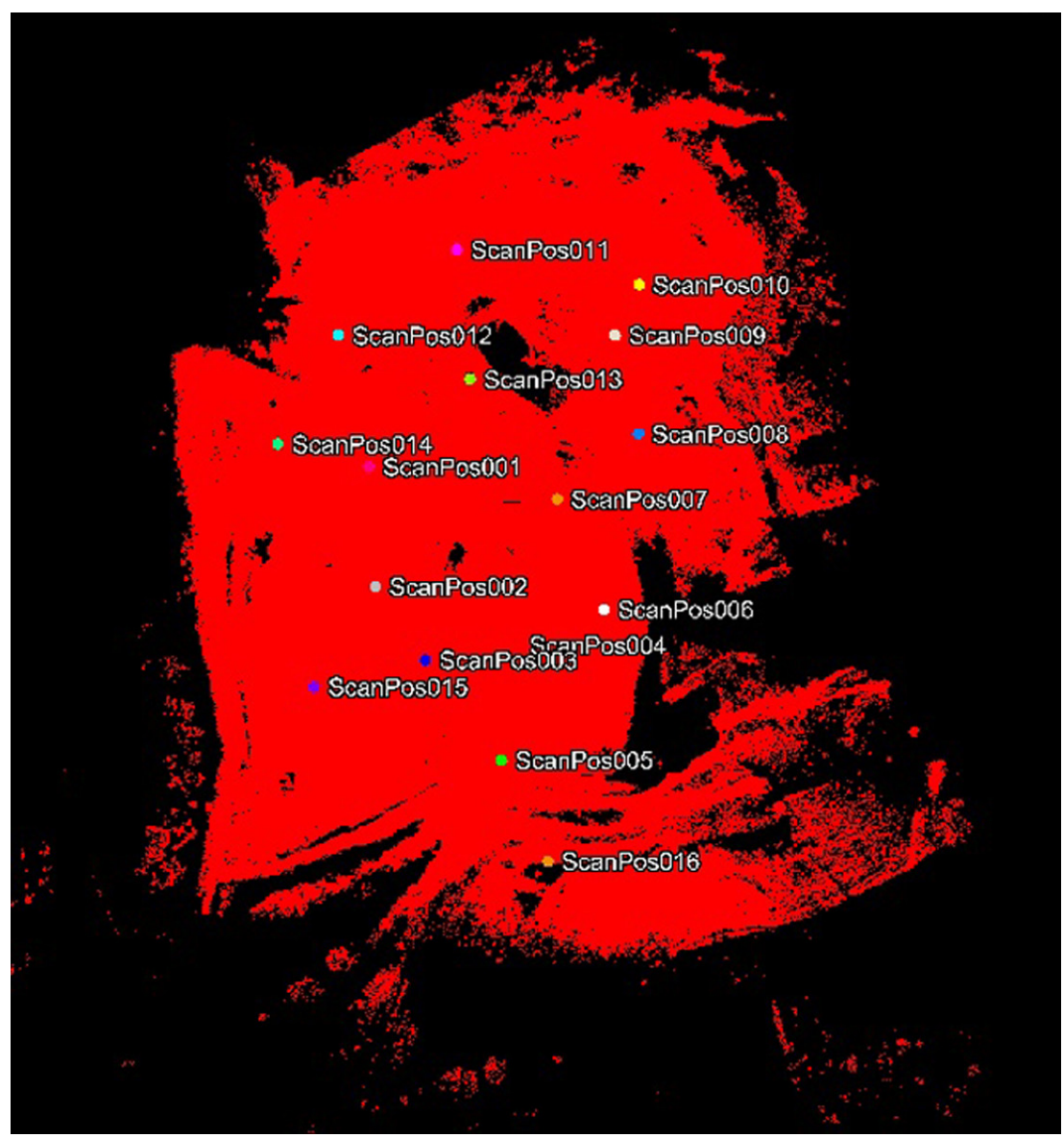

Figure 1. Location of sites in the Gorce I quarry where laser scanning was conducted Rysunek 1. Miejsca z których wykonano skaning laserowy w kamieniołomie Gorce I 


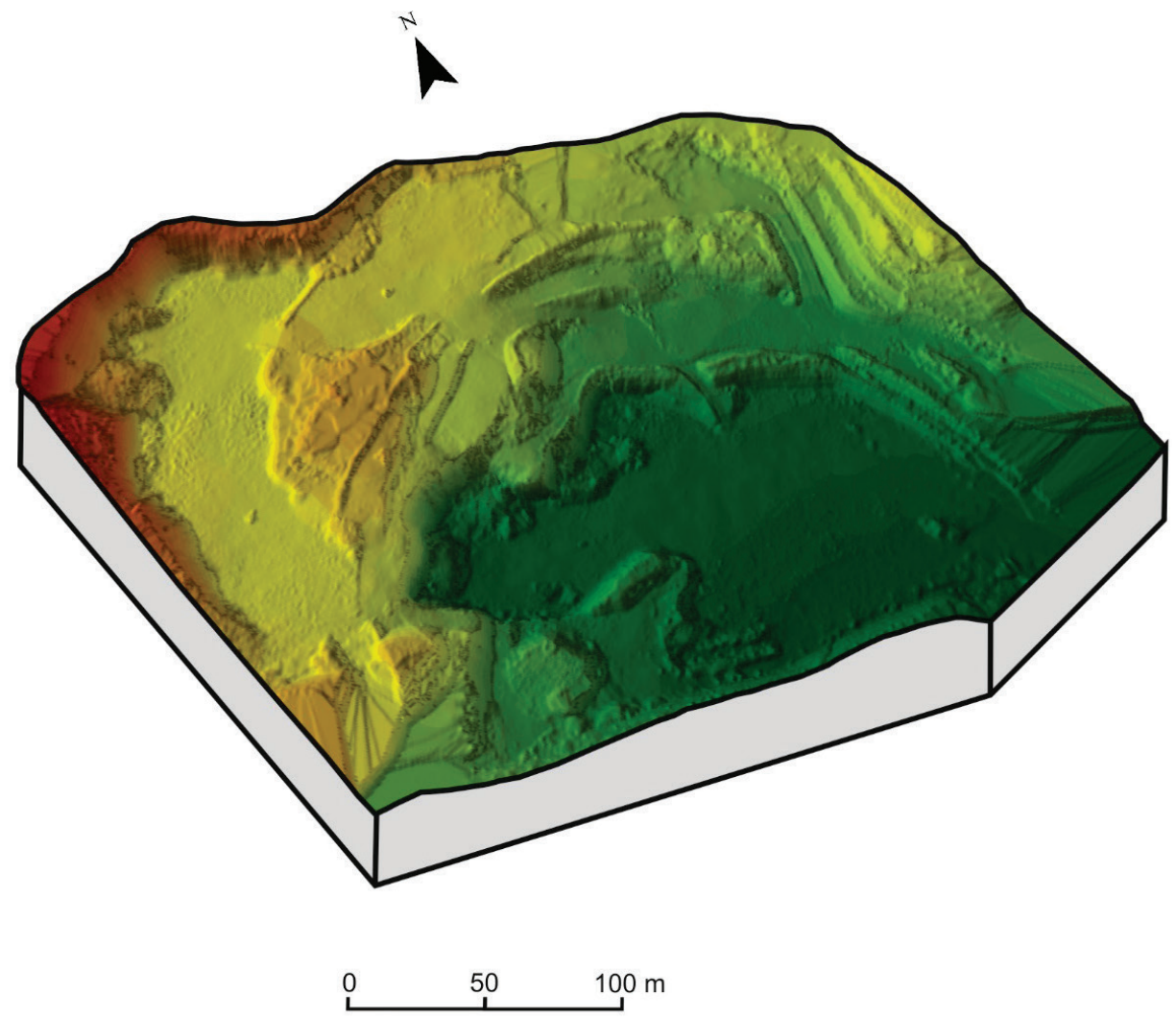

Altitude data for the quarry/ Wysokości bezwzględne w kamieniołomie

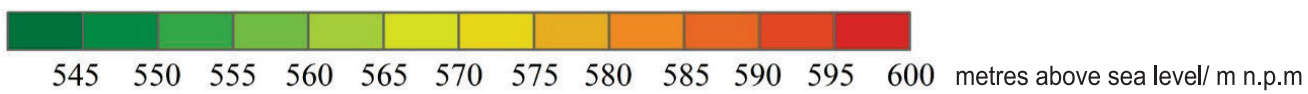

Figure 2. A 3D model of the Gorce I quarry (a perspective view)

Rysunek 2. Model 3D kamieniołomu Gorce I (widok w rzucie perspektywicznym)

of an adult Pole was assumed to be $172 \mathrm{~cm}$ (http:// www.newsweek.pl/...). This analysis allowed for determining the visibility of the quarry walls from the adopted point.

The conducted studies were enriched with photographic documentation.

\section{The Gorce I quarry}

The Gorce I quarry (Figure 3) is located within the area of porphyry deposits. According to J. Kondracki's physical-geographical division (1978) the deposit is located in the Central Sudetes within the Wałbrzyskie Mountains $(332,42)$. Administratively, it is located in the commune of Boguszów Gorce in Wałbrzych county.

Porphyry deposits in the Gorce I quarry cover an area of 15.51 ha. It is located on a nameless hill reaching 581.1-meter elevation above sea level. The hill is elongated in the north-south direction with a deviation to the south. The area surrounding the hill from the north and south is relatively flat and reaches $500 \mathrm{~m}$ above sea level (Lis 1996).

The porphyry deposit of Gorce I is situated in the western part of Wałbrzych basin, which is a part of the intra-sudetic depression, also known as intrasudetic basin or intra-sudetic synclinorium (Oberc 1972). This deposit is one of the links in the eastern www.newsweek.pl/...). Analiza ta pozwoliła na określenie widoczności ścian kamieniołomu z przyjętego punktu.

Przeprowadzone badania wzbogacono o dokumentację fotograficzną.

\section{Kamieniołom Gorce I}

Kamieniołom Gorce I (rysunek 3) znajduje się w obrębie złoża porfirów. Według podziału fizyczno-geograficznego J. Kondrackiego (1978) złoże położone jest w Sudetach Środkowych w obrębie Gór Wałbrzyskich (332.42). Administracyjnie znajduje w gminie Boguszów Gorce w powiecie wałbrzyskim.

Złoże porfirów w kamieniołomie Gorce I ma powierzchnię 15,51 ha. Zlokalizowane jest na bezimiennym wzgórzu o wysokości 581,1 m n.p.m. Wzgórze to wydłużone jest w kierunku równoleżnikowym z odchyleniem ku południowi. Teren otaczający wzgórze od północy i południa jest stosunkowo płaski i wznosi się do rzędnej 500 m n.p.m (Lis 1996).

Złoże porfirów Gorce I położone jest w zachodniej części niecki wałbrzyskiej, stanowiącej część depresji śródsudeckiej, zwanej też niecką wewnętrznosudecką lub synklinorium śródsudeckim (Oberc 1972). Złoże jest jednym z ogniw w paśmie wychodnim por- 


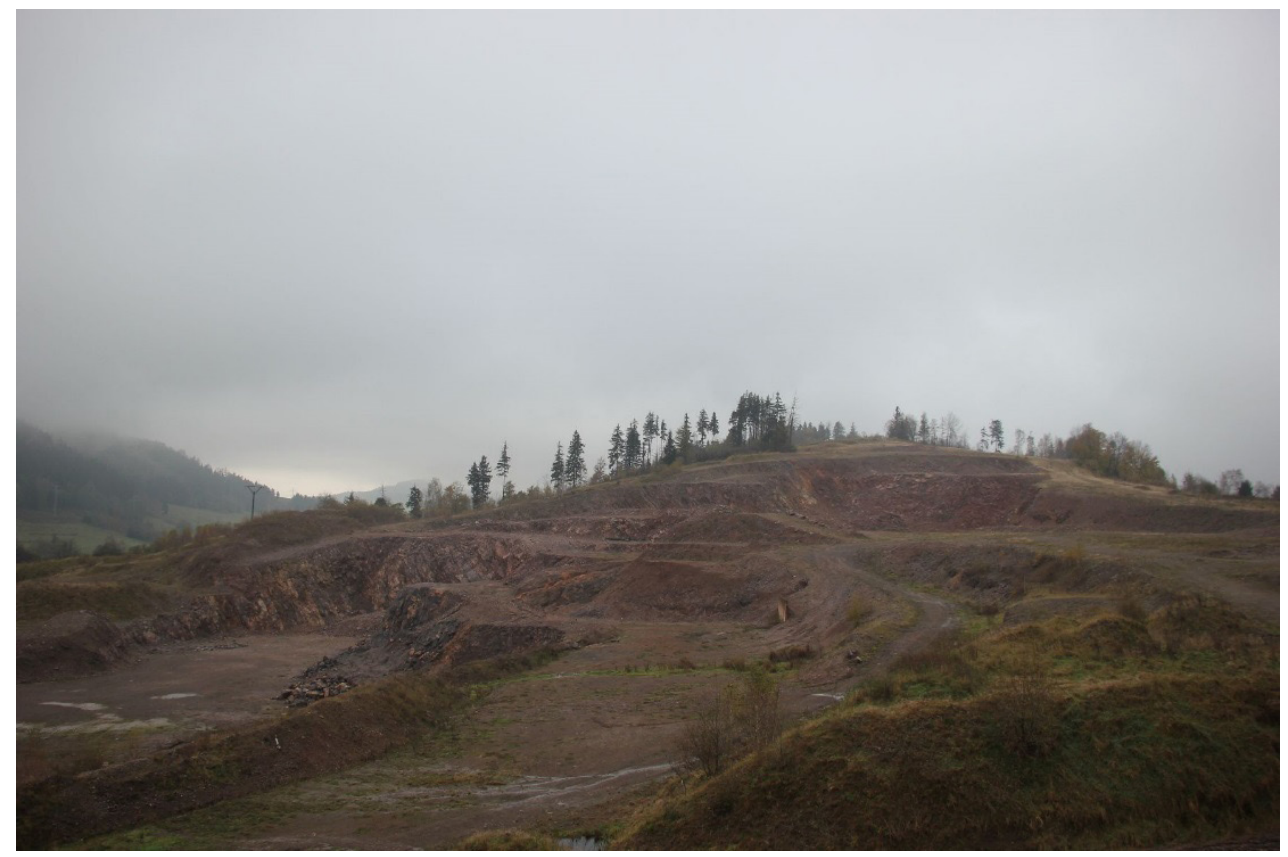

Figure 3. A view of the Gorce I quarry from the east (author: $Ł$. Zbucki)

Rysunek 3. Widok na kamieniołom Gorce I ze wschodu (autor: Ł. Zbucki)

porphyry band on the border of Upper Carboniferous strata, represented by Żaclerz formation (sedimentary rocks in this area) and Rotliegend deposits in the forms of conglomerates, sandstones and mudstones of the Upper Carboniferous era (Lis 1996). Eastern porphyry deposits are marked in the terrain morphology and stretch from Czarny Bór in the north-west to Stary Lesiniec in the south-east as a series of plane-convex lenses. The geological form of porphyry occurrence is ambiguous. According to some sources these are magma traps while others consider them as sills (Lis 1996).

The porphyry lens lies on top on, or almost on top, of Żaclerz sandstones and conglomerates deposited along the north-west to south-east line and slumping in the south-west direction at an angle of 40-50 degrees $^{\circ}$. River sand deposits lie above them, at an angle ${ }^{\circ}$ of 30-45 degrees to the south-west (Lis 1996).

Porphyry within the deposit area occurs in the form of intrusion reaching up to $80 \mathrm{~m}$ in height (Lis 1996 Cwojski, Kozdrój 2007). The porphyry occurring in this deposit does not exhibit considerable diversity in terms of mineral composition. Porphyry is an aphanitic volcanic groundmass with rare phenocysts. The colour of the rock ranges from greypurple through grey-pink to grey-yellow with creamy phenocrysts (Figure 5). The porphyry occurring in the deposit is heavily cracked, irregularly in all directions (there are no cracks only in the southeast direction) (Figure 4) and at all levels (Cwojski, Kozdrój 2007).

In the area of the quarry pit there are no groundwater or aquifer levels (Figure 3 ) and the exploitation conducted in the years 2000 to 2013 (http: //walbrzych.naszemiasto.pl / ...) did not contribute to the creation of a water reservoir in firów na pograniczu karbonu górnego, reprezentowanego przez warstwy żaclerskie i osadów czerwonego spagowca wykształconego jako zlepieńce, piaskowce i mułowce wieku górnokarbońskiego (Lis 1996). Wychodnie porfirów zaznaczają się w morfologii terenu i rozciągają się od czarnego Boru na NW po Stary Lesiniec na SE jako szereg płasko-wypukłych soczewek. Forma geologiczna wystąpień porfiru nie jest jednoznaczna. Według jednych to wylewy, a według innych to żyły pokładowe (Lis 1996).

Soczewa porfiru leży zgodnie lub prawie zgodnie na piaskowcach i zlepieńcach żaclerskich zalegających NW-SE i zapadających w kierunki SW pod kątem 40-50 . Nad nimi zalegają piaski rzeczne pod kątem 30-45 na SW (Lis 1996).

Porfiry w obrębie złoża występują $\mathrm{w}$ formie intruzji do 80 m wysokości (Lis 1996, Cwojski, Kozdrój 2007). Porfir występujący w złożu nie wykazuje większego zróżnicowania pod względem składu mineralnego. Porfir jest skałą z afanitowym ciastem wulkanicznym i rzadkimi prakryształami. Barwa skały jest zmienna od szaro-fioletowej przez szaro-różową do szaro-żółtej z kremowymi prakryształami (rysunek 5). Porfiry występujące w złożu są silnie spękane nieregularnie we wszystkich kierunkach (brak spękań tylko w kierunku SE) (rysunek 4) i na wszystkich poziomach (Cwojski, Kozdrój 2007).

Na terenie wyrobiska nie występują wódy gruntowe i poziomy wodonośne (rysunek 3) a prowadzona eksploatacja w latach 2000-2013 (http://walbrzych. naszemiasto.pl/...), nie przyczyniła się do powstania w wyrobisku zbiornika wodnego (Lis 1996). Wyrobisko zasilane jest jedynie przez wody opadowe. Na południe od wyrobiska przepływa rzeka Lesk, która jest prawym dopływem Bobru. Na zachodzie od kamieniołomu przepływa Czerwony Strumień, dopływ 
the quarry pit (Lis 1996). The quarry pit is supplied only with rainwater. The Lesk river, which is a right tributary of the Bóbr river, flows to the south of the pit. To the west of the quarry the Czerwony Strumien (a stream) flows - a tributary of the Lesk river. The exploitation which is being conducted does not affect the hydrological conditions, apart from changing the direction of the flow within the quarry pit area. rzeki Lesk. Prowadzona eksploatacja nie wpływa na warunki hydrologiczne, poza zmianą kierunku spływu w obrębie wyrobiska.

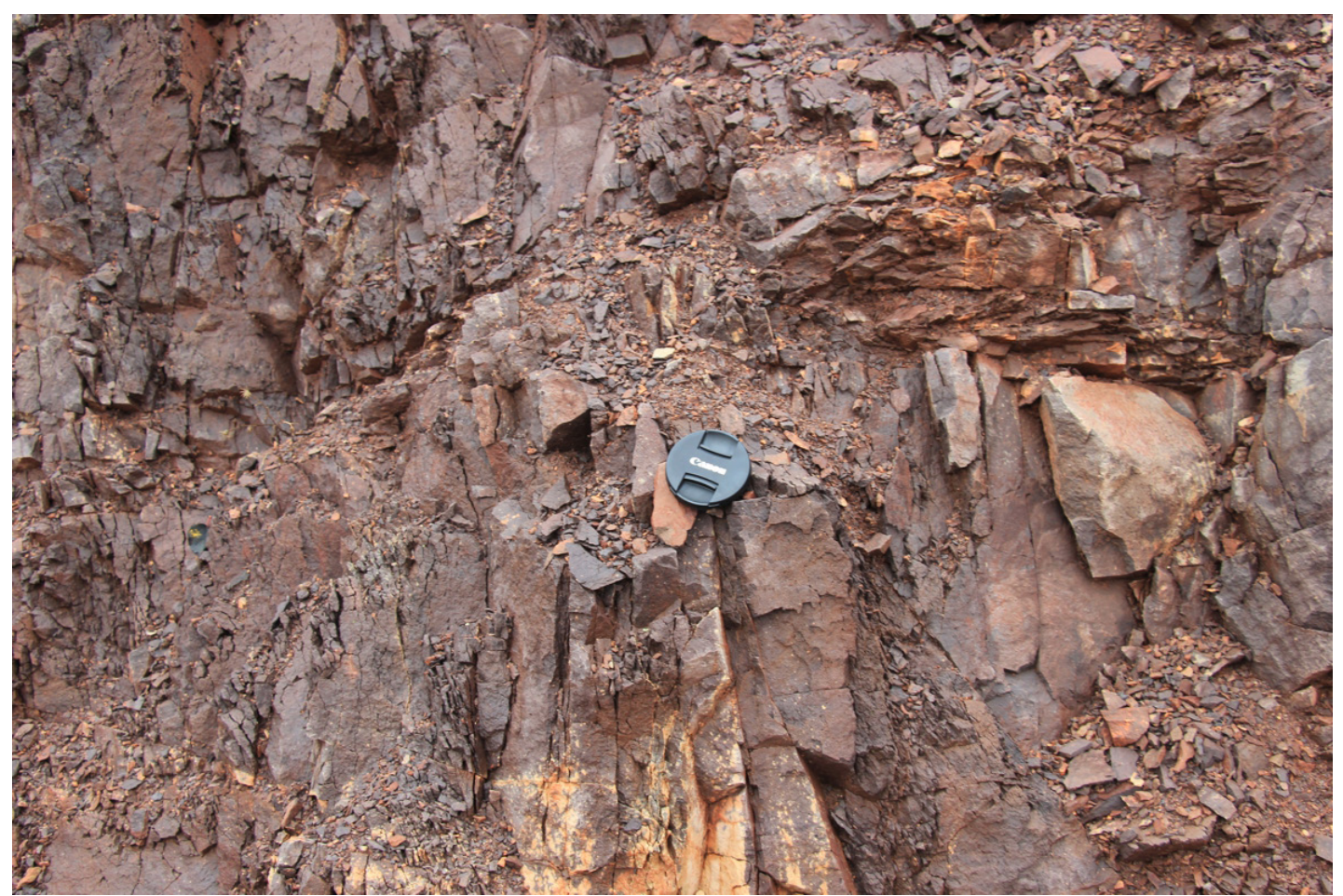

Figure 4. Porphyry cracks in Gorce I deposit (author: Ł. Zbucki) Rysunek 4. Spękania porfirów w złożu Gorce I (autor: Ł. Zbucki)

Gorce I deposit is covered with an overburden of $1 \mathrm{~m}$ to $3.9 \mathrm{~m}$ in thickness (on average $2.5 \mathrm{~m}$ ). The exploitation of the deposit is conducted mechanically. The deposit has the form of a lens with an area of 15.51 hectares, where the thickness of the mineral ranges from $15.7 \mathrm{~m}$ to $106 \mathrm{~m}$ (on average $63.2 \mathrm{~m}$ ). Because of the heavy cracking of the deposit (Figure 4) the mineral is suitable only for crushed stone, which is used mainly in road and hydrotechnical construction (Nov 1996).

The quarry pit is located in the vicinity of the buffer zone of Sudety Wałbrzyskie Landscape Park. The conducted exploitation has led to mechanical and soil-hydrological transformations and resulted in risks associated with the drilling and blasting technique (noise, dust) (Lis 1996). After closing the Gorce I quarry land reclamation works are planned with regard to forest and water conditions (http: // geoportal.pgi.gov.pl/midas-web/pages/rog ...).

\section{Natural features that may have an impact on the tourist attractiveness of the Gorce I quarry}

Porphyry was exploited in the Gorce quarry in the years 2000-2013 (http: //walbrzych.naszemiasto. pl / ...). The rocks occurring in the deposit range in
Złoże Gorce I przykryte jest nadkładem o miąższości od $1 \mathrm{~m}$ do 3,9 m (śr. 2,5 m). Eksploatacja w złożu prowadzona jest mechanicznie. Złoże ma forme soczewki o powierzchni 15,51 ha, w której miąższość kopaliny waha się od 15,7 m do $106 \mathrm{~m}$ (śr. 63,2 m). Silne spękania złoża (rysunek 4) powodują, że kopalina nadaje się tylko na kruszywo łamane, które ma zastosowanie głównie w budownictwie drogowym i hydrotechnicznym (Lis 1996).

Wyrobisko położone jest w sąsiedztwie otuliny Parku Krajobrazowego Sudetów Wałbrzyskich. Prowadzona eksploatacja spowodowała przekształcenia mechaniczne i hydrologiczno-glebowe oraz wywoływała zagrożenia związane z robotami strzałowymi (hałas, zapylenie) (Lis 1996). Po zamknięciu kamieniołomu Gorce I planowana jest rekultywacja terenu w kierunku leśnym i wodnym (http://geoportal.pgi. gov.pl/midas-web/pages/rog...).

\section{Cechy naturalne mogące wpływać na atrakcyj- ność turystyczną kamieniołomu Gorce I}

W kamieniołomie Gorce I w latach 2000-2013 eksploatowano porfiry (http://walbrzych.naszemiasto. pl/...). Występujące w złożu skały wykazują zmienną 
colour from grey-purple through grey-pink to greyyellow (Figure 5) There are spots on the quarry pit walls where one can see the precipitation of copper and dendrite compounds (Figure $5 \mathrm{~h}$ ). The porphyry occurring here is very heavily cracked. There are shear zones visible among the cracks (Figure 4). There are also fragments of rocks in the deposit, in which there are visible elements of selective weathering (Figure 5e).

There are no effusions of groundwater nor water reservoirs in the pit. However, there are opportunities for adapting these geological profiles for the purposes of tourism.

In the vicinity of the quarry there are outcrops of conglomerates that may be an additional tourist attraction.

\section{Anthropogenic features that may have an impact on the tourist attractiveness of the Gorce I quarry}

Maximum height differences of the terrain in the Gorce I quarry reach about $52 \mathrm{~m}$ (Figure 1). The accessibility of the quarry pit with various means of transport is very good. There are no major obstacles to its accessibility, even by car. The exploitation of the Gorce I quarry started in 2005, currently (2016) it is suspended.

The quarry is about $13 \mathrm{~km}$ away from the nearest national road, and the nearest marked tourist trail is about $4.5 \mathrm{~km}$ away.

Along the nearest road running nearby the quarry, an earth dike has been constructed using the overburden material occurring in the deposit. This way, the Gorce I quarry pit is invisible from the nearest paved road, causing it to have a very small impact on the landscape.

\section{The perspective of geotourist development of the Gorce I quarry}

In the Gorce I quarry pit all the qualities important for geotourism, with the exception of landscape qualities, are already at the lowest level of exploitation usefulness. The following are found here: faults, rock fractures, traces of selective weathering, precipitation of copper compounds, dendrites, variable rock coloration. To the north of the quarry pit, approximately $200 \mathrm{~m}$ towards the railway siding, in outcrops lying along the road, there occur conglomerates.

Information boards should be placed in the area of the quarry pit:

- at the entrance to the pit (Figure 6), a board should be placed with information about the geological structure of the region's deposits and magmatic processes owing to which the deposit was created,

- another board should describe the diversity of rocks occurring here (Figure 6). It should contain photographs of individual rocks (phenocrysts) of different colours and sizes,

- the third board (Figure 6) would describe tectonic processes occurring here, among kolorystykę od szaro-fioletowej przez szaro-różową do szaro-żółtej (rysunek 5) Na ścianach wyrobiska znajdują się miejsca, w których dostrzec można wytrącenia związków miedzi oraz dendrytu (rysunek 5h). Występujące tutaj porfiry są bardzo silnie spękane, wśród spękań widoczne są uskoki (rysunek 4). W złożu występuja również fragmenty skał, w których widoczne są elementy selektywnego wietrzenia (rysunek 5e).

W wyrobisku nie występują wysięki wód gruntowych oraz zbiorniki wodne. Natomiast istnieją możliwość adaptacji profili geologicznych dla potrzeb turystyki.

W sąsiedztwie kamieniołomu znajdują się wychodnie zlepieńców, które mogą być dodatkową atrakcją turystyczną.

\section{Cechy antropogeniczne mogace wpływać na atrakcyjność turystyczną kamieniołomu Gorce I}

Maksymalne deniwelacje terenu $\mathrm{w}$ kamieniołomie Gorce I wynoszą około 52 m (rysunek 1). W wyrobisku występują bardzo dobre warunki komunikacyjne. Brak jest większych utrudnień w ruchu, nawet samochodem. Eksploatację w kamieniołomie Gorce I rozpoczęto w roku 2005, obecnie (2016) jest wstrzymana.

Kamieniołom oddalony jest od najbliższej drogi krajowej około $13 \mathrm{~km}$, a od najbliższego znakowanego szlaku turystycznego około $4,5 \mathrm{~km}$.

Wzdłuż najbliższej drogi znajdującej się przy kamieniołomie usypano wał ziemny z nadkładu występującego w złożu. W związku z tym wyrobisko Gorce I jest niewidoczne z najbliższej drogi utwardzonej, powodując jego bardzo małe odziaływanie krajobrazowe.

\section{Perspektywa zagospodarowana geoturystyczne- go kamieniołomu Gorce I}

W wyrobisku Gorce I wszystkie walory geoturystyczne, poza walorami krajobrazowymi, znajdują się już na najniższym poziomie eksploatacyjnym. Występują tutaj: uskoki, spękania skał, ślady selektywnego wietrzenia, wytrącenia związków miedzi, dendryty, zmienna kolorystyka skał. Na północ od wyrobiska, w odległości około $200 \mathrm{~m}$ w kierunku bocznicy kolejowej, w odsłonięciach biegnących wzdłuż drogi występują zlepieńce.

Na terenie wyrobiska powinny znaleźć się tablice informacyjne:

- przy wejściu do wyrobiska (rysunek 6) należy umieścić tablicę informującą o budowie geologicznej regionu złoża oraz przebiegu procesów magmowych, dzięki którym powstało to złoże,

- kolejna tablica powinna opisywać występującą tutaj różnorodność skał (rysunek 6). Należałoby zaprezentować na niej fotografie poszczególnych skał zróżnicowanych kolorystycznie oraz wielkościa fenokryształów,

- trzecia tablica (rysunek 6) opisywałaby występujące tutaj procesy tektoniczne, między inny- 

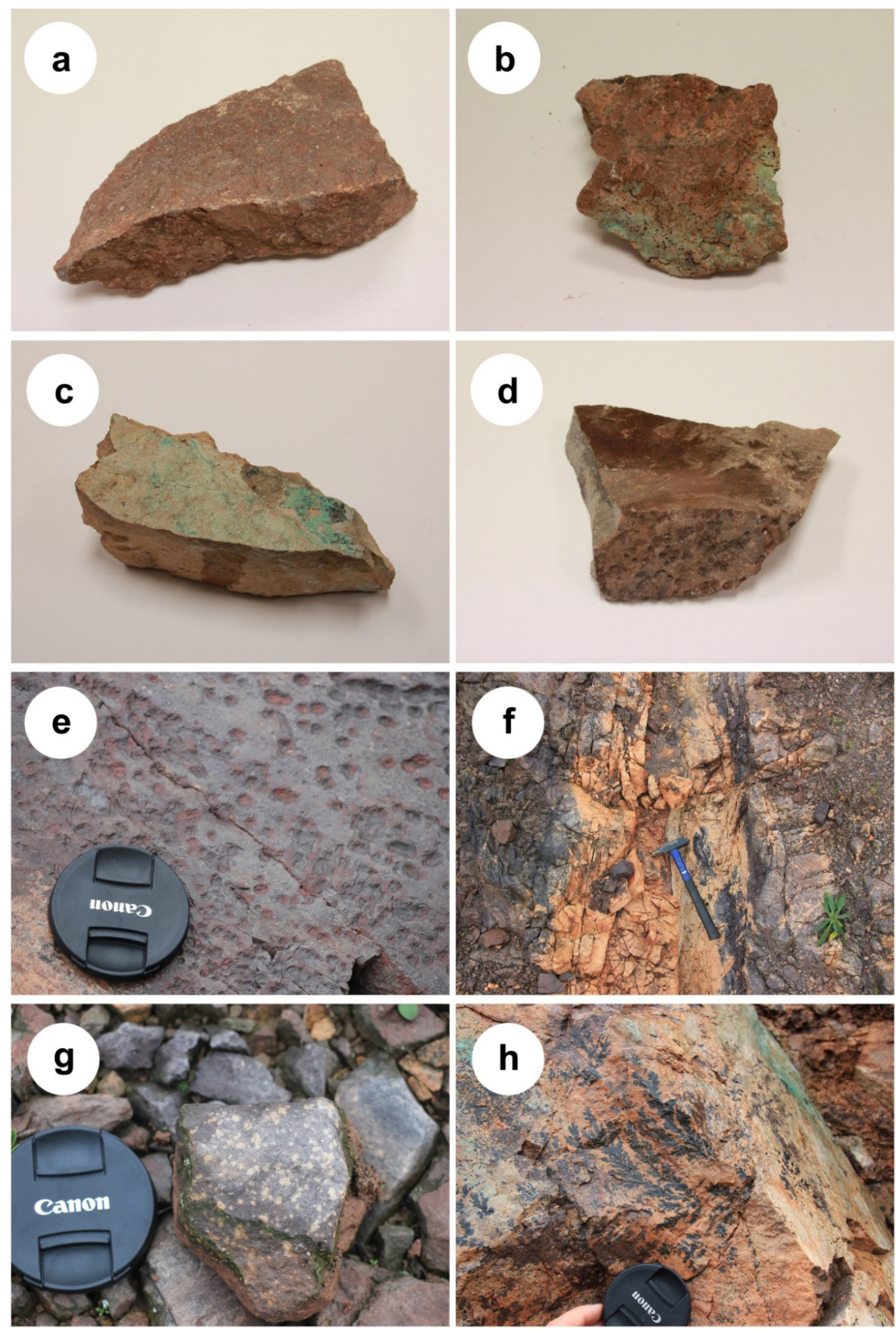

Figure 5. The porphyry forms from the Gorce I deposit: a - porphyry with visible feldspar phenocrysts of up to $2 \mathrm{~mm}$ in size, b - brown porphyry with visible copper compounds, c - light pink porphyry with copper compounds, d -porphyry with visible feldspar phenocrysts up to $3 \mathrm{~mm}$ in size with a visible dendrite, on the weathered surfaces secondary minerals (weatheringrelated) - iron oxides are visible, e - porphyry with visible weathering structures with visible iron oxides, $\mathrm{f}$ - brown and light pink porphyry in the wall of the quarry, $\mathrm{g}$ - porphyry with visible feldspar phenocrysts of up to $3 \mathrm{~mm}$ in size, $\mathrm{h}$ - porphyry of a light pink colour with visible copper compounds and dendrite (author: Ł. Zbucki)

Rysunek 5. Porfiry złoża Gorce I: a - porfir z widocznymi fenokryształami skaleni o wielkości do 2 mm, b - porfir barwy brunatnej z widocznymi związkami miedzi, c - porfir barwy jasnoróżowej z widocznymi związkami miedzi, d -porfir z widocznymi fenokryształami skaleni o wielkości do $3 \mathrm{~mm}$, z widocznym dendrytem, na powierzchniach wietrzeniowych widoczne minerały wtórne (wietrzeniowe) tlenki żelaza, e - porfir z widocznymi strukturami wietrzeniowymi z widocznymi tlenkami żelaza, f - porfir barwy brunatnej i jasnoróżowej w ścianie kamieniołomu, g - porfir z widocznymi fenokryształami skaleni, o wielkości do $3 \mathrm{~mm}$, h - porfir jasnoróżowy z widocznymi związkami miedzi i dendrytem (autor: Ł. Zbucki) 

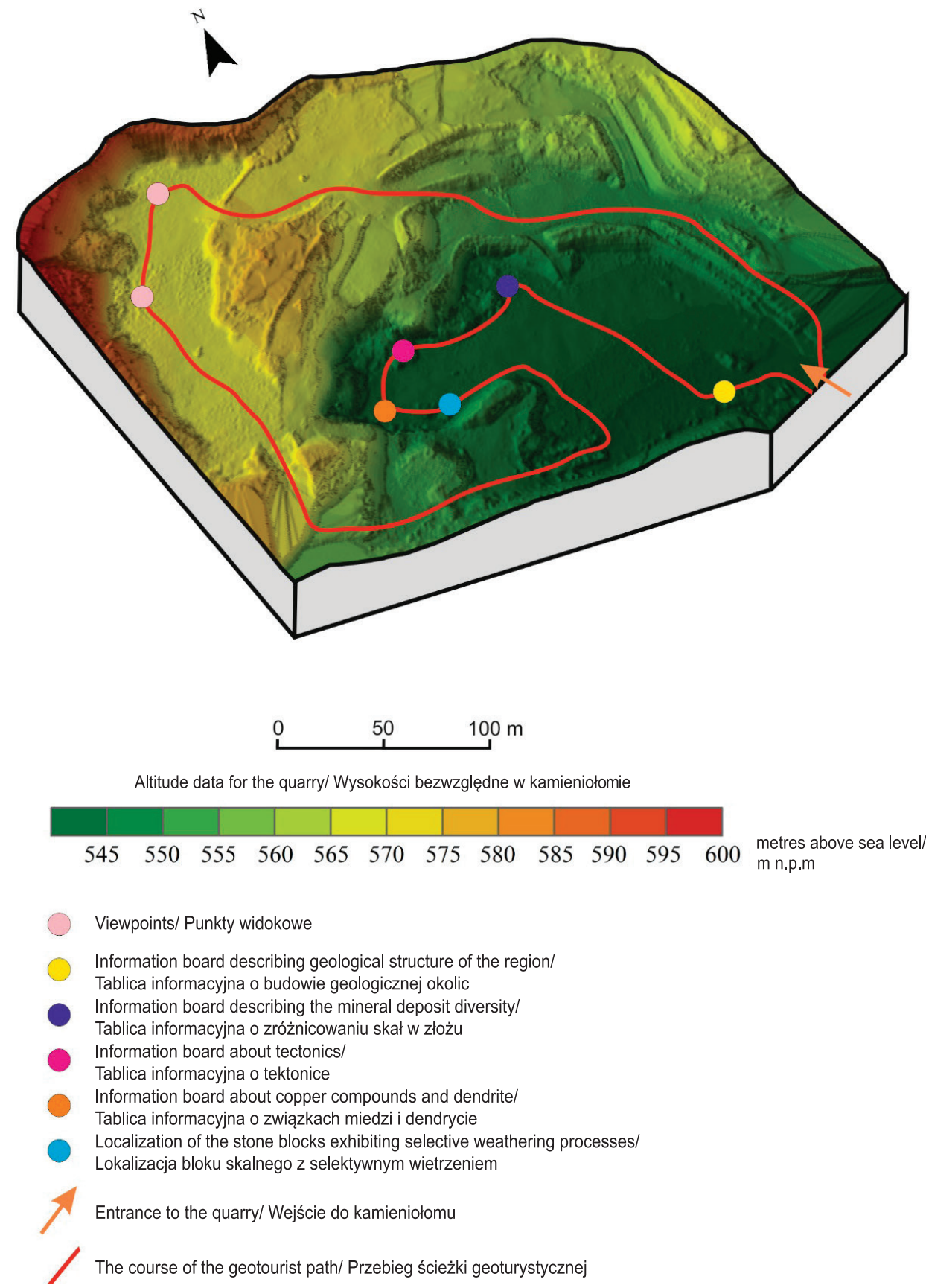

Figure 6. The placement of information boards in the Gorce I quarry pit (a perspective view, the author's own development) Rysunek 6. Rozmieszczenie tablic informacyjnych w wyrobisku Gorce I (widok w rzucie perspektywicznym, opracowanie własne)

others: the faults and strong cracking and the influence of cracking on weathering,

- the fourth table (Figure 6) presents the characteristics of copper precipitation and dendrite occurring on the quarry wall,

- next to one of the specially selected stone blocks an information board describing the processes of selective weathering which affect it, should be placed.

- despite being located outside of the quarry pit, the sites where conglomerates occur should receive an information board describing the mi: uskoki i silne spękania oraz wpływy spękań na wietrzenie,

- czwarta tablica (rysunek 6) scharakteryzuje występujące w ścianie kamieniołomu wytrącenia związków miedzi i dendryt,

- przy jednym ze specjalnie wybranych bloków skalnych powinna znaleźć się tablica informacyjna, opisująca zachodzące na nim procesy selektywnego wietrzenia,

- pomimo położenia poza samym wyrobiskiem miejsca, gdzie występują zlepieńce, warto przy nich zlokalizować tablicę informacyjną opisują- 
process of their creation. The conglomerates occurring here have valuable visual aesthetic qualities,

At higher levels of the pit face the geoattractions described above occur as well, but they are not as impressive as the ones at the lowest level of the quarry pit face, hence the upper levels of the pit should be used as terraces from which you can admire the landscape attractions.

Analyses of the visibility of the quarry walls which were conducted (Figure 7) demonstrate that a tourist visiting the lowest level of the quarry pit and viewpoints is able to see the most interesting parts of the mine. cą proces ich powstania. Występujące tutaj zlepieńce posiadają cenne walory wizualne,

$\mathrm{Na}$ wyższych poziomach eksploatacyjnych występują też opisane powyżej geoatrakcje, jednak nie są one tak okazałe jak na najniższym poziomie kamieniołomu, dlatego górne poziomy eksploatacyjne powinny być wykorzystane jako tarasy widokowe, z których można podziwiać walory krajobrazowe.

Przeprowadzone analizy widoczności ścian kamieniołomu (rysunek 7) wskazują, że turysta zwiedzając najniższy poziom wyrobiska i punkty widokowe jest w stanie zobaczyć najciekawsze fragmenty kopalni.

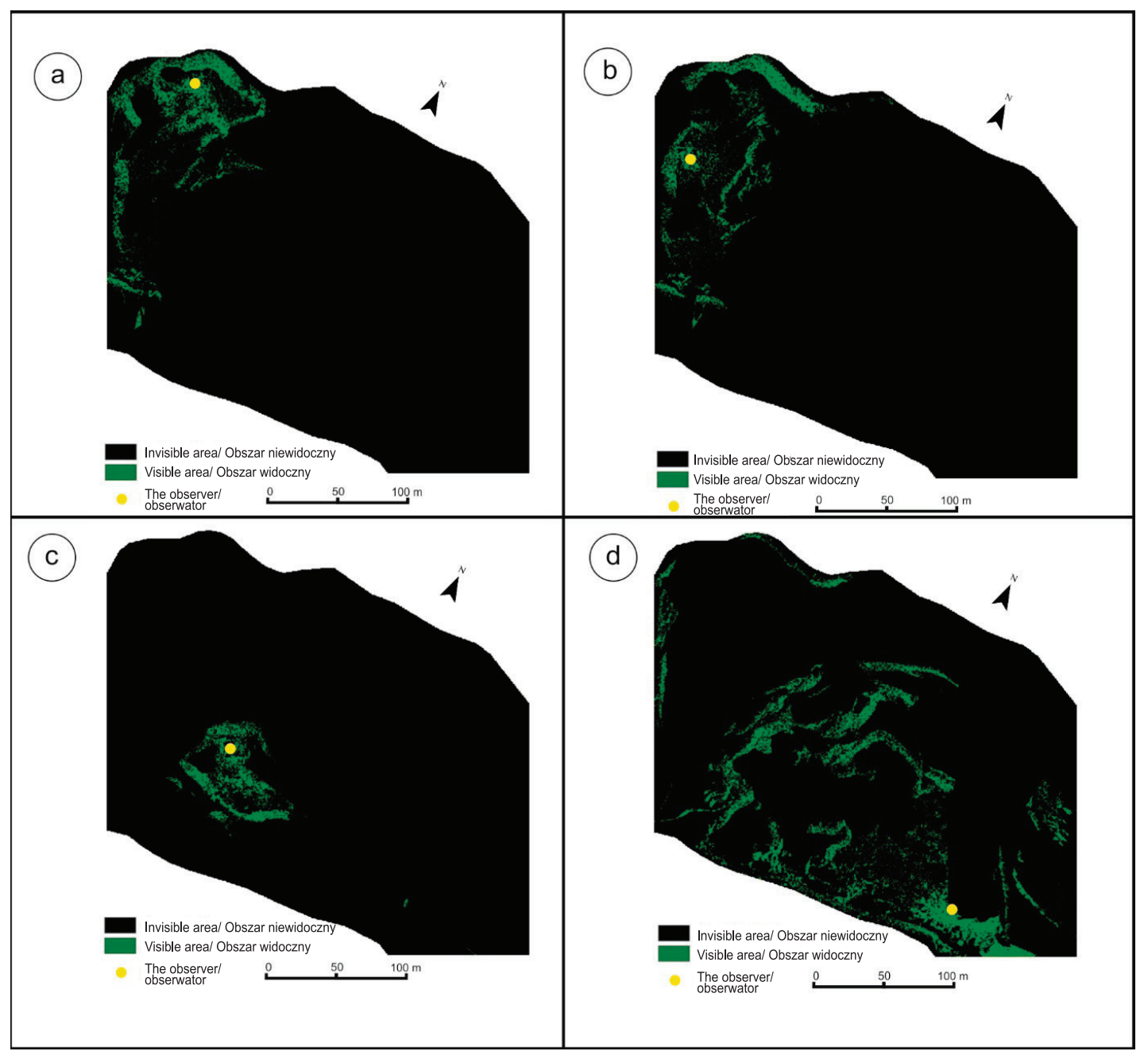

Figure 7. Visibility analysis in the Gorce I quarry: a - from the viewpoint $1, \mathrm{~b}$ - from the viewpoint 2 , $\mathrm{c}$ - at the location of the information board about tectonics, $\mathrm{d}$ - at the entrance to the quarry pit

Rysunek 7. Analiza widoczności w kamieniołomie Gorce I: a - z puntu widokowego 1, b - z puntu widokowego 2, c - w miejscu lokalizacji tablicy o tektonice, d - przy wejściu do wyrobiska

\section{Conclusions}

The porphyry varieties occurring in the Gorce I quarry have been considerably transformed by tectonic processes. There are numerous effects of processes such as precipitation of copper compounds, selective weathering or dendrite.

\section{Wnioski}

Porfiry występujące w kamieniołomie Gorce I są silnie przekształcone przez procesy tektoniczne. Występują tutaj liczne efekty procesów np. wytrącenia związków miedzi, selektywne wietrzenie czy dendryt. 
The study allowed for the possibility of using the Gorce I quarry for geotourism purposes. The course of the geotourist path has been developed. It covers the most interesting places of excavation and location of information boards. The 3D models which have been developed allowed for a detailed analysis of the studied area. The performed 3D scans were used for verifying the course of the path. The performed analysis of visibility allowed for the optimal selection of sites for the location of information boards and viewpoints.

The study confirmed the possibility of using the Gorce I quarry for geotourism purposes. However, it is not certain if the adaptation of the quarry pit will proceed in this direction as there is an ongoing search for an investor to conduct further exploitation of rock resources. The current exploitation licence envisages reclamation focused on forest and water environment. This direction of land reclamation at the moment is hindered, because on the site of the quarry pit there is only rain water supply. In order to conduct land rehabilitation in the quarry pit with the focus on hydrological conditions there should be a change of the quarry pit type from a slope shape to a slope with a ditch, which can cause problems during exploitation, and perform appropriate works associated with supplying water. The conducted research confirms that the quarry pit can be used for geotourism purposes and applying this method of land restoration could be considered for the Gorce I quarry pit to give it a second life.
Przeprowadzone badania pozwoliły na wskazanie możliwości wykorzystania wyrobiska Gorce I dla potrzeb geoturystyki. Opracowano i wytyczono przebieg ścieżki geoturystycznej obejmującej najciekawsze miejsca wyrobiska i zlokalizowano tablice informacyjne. Wykonane modele 3D pozwoliły na szczegółową analizę badanego terenu. Wykonane skany 3D wykorzystano podczas weryfikacji przebiegu ścieżki. Przeprowadzona analiza widoczności pozwoliła na optymalny dobór miejsc do lokalizacji tablic informacyjnych oraz punktów widokowych.

Badania potwierdziły również możliwości wykorzystania kamieniołomu Gorce I dla potrzeb geoturystyki. Jednak nie jest pewnie czy taka adaptacja tego wyrobiska nastąpi, ponieważ trwają poszukiwania inwestora do prowadzenia dalszej eksploatacji skał. Obecna koncesja eksploatacyjna przewiduje rekultywację w kierunku leśnym i wodnym. Ten kierunek rekultywacji obecnie jest utrudniony, gdyż na terenie wyrobiska występuje jedynie woda opadowa. W celu rekultywacji wyrobiska w kierunku wodnym należałoby dokonać zmiany typu wyrobiska z stokowego na wgłębno-stokowy, co może stwarzać problemy przy prowadzonej eksploatacji. Należałoby także wykonać odpowiednie prace związane ze sprowadzeniem wody Przeprowadzone badania potwierdzają, że wyrobisko można wykorzystać dla potrzeb geoturystyki i może warto dla wyrobiska Gorce I, uwzględnić ten kierunek rekultywacji, który może dać kamieniołomowi drugie życie.

\section{References/Literatura:}

1. Chwastek J., Janusz W. (1992), Kamieniołom - „rana w krajobrazie”, czy zabytek przyrody nieożywionej? Zesz. Nauk. AGH, Górnictwo, 16/2, s. 135-143.

2. Cwojski S., Kozdrój W. (2007), Sudety. Przewodnik geoturystyczny. PIG, Warszawa.

3. González-Aguilera D., Fernández-Hernández J., Mancera-Taboada J., Rodríguez-Gonzálvez P., Hernández-López D., FelipeGarcía B., Gozalo-Sanz I., Arias-Perez B. (2012), 3D Modelling and accuracy assessment of granite quarry using unmmanned aerial vehicle. ISPRS Annals of the Photogrammetry, Remote Sensing and Spatial Information Sciences, Volume I-3, 2012, XXII ISPRS Congress, 25 August - 01 September 2012, Melbourne, Australia.

4. Janočková J., Koščová M., Jablonská J. (2012), Consideration of geological and ecological factors in tourist trail planning: Case study of the Suchá Belá Gorge (Slovakia). Acta Geoturistica, t. 3, n. 2, s. 1-8.

5. Kasztelewicz Z., Ptak M. (2011), Rekultywacja terenów pogórniczych w kopalniach surowców skalnych. Prace Naukowe Instytutu Górnictwa Politechniki Wrocławskiej nr 39, Studia i Materiały nr 132, s. 165-178.

6. Kondracki J. (1978), Geografia fizyczna Polski. PWN, Warszawa.

7. Kovanič L., Blišt’an P. (2014), Quarry wall stability assessment using TLS method. Advanced Materials Research Vols. 10441045 (2014), s. 603-606.

8. Lis B. (1996), Uproszczona dokumentacja geologiczna w kat. C1 i C2 złoża porfiru „Gorce” w miejsc. Gorce.

9. Nita J. (2013), Zmiany w krajobrazie powstałe w wyniku działalności górnictwa surowców skalnych na obszarze Wyżyn Środkowopolskich. UŚ, Katowice.

10. Oberc J. (1972), Budowa geologiczna Polski, t. IV Tektonika, cz. 2, Sudety i obszary przyległe. Wydawnictwo Geologiczne, Warszawa.

11. Prawo geologiczne i górnicze Dz. U. Nr. 228, poz. 1947 z późn. zm (art. 80 ust.1 pkt 5 ustawy z dnia 4 lutego 1994r.).

12. Słomka T., Kicińska-Świderska A. (2004), Geoturystyka - podstawowe pojęcia. Geoturystyka, 1 (1), s. 5-7.

13. http://geoportal.pgi.gov.pl/midas-web/pages/index.jsf?conversationContext=1 (data dostępu: 21.07.2016).

14. http://walbrzych.naszemiasto.pl/artykul/kamieniolom-w-boguszowie-do-sprzedazy,2413275,art,t,id,tm.html_(data dostępu: 21.07.2016).

15. http://www.newsweek.pl/nauka/kto-jest-najwyzszy-w-europie-ile-wzrostu-ma-statystyczny-polak,artykuly,360767,1. html_(data dostępu: 21.07.2016).

16. http://geoportal.pgi.gov.pl/midas-web/pages/rog/wyszukaj_obszar.jsf?conversationContext=1 (data dostępu: 21.07.2016). 